\title{
Evolutionary Patterns in Pearl Oysters of the Genus Pinctada (Bivalvia: Pteriidae)
}

\author{
Regina L. Cunha ${ }^{1,{ }^{*}}$, Françoise Blanc ${ }^{3}$, François Bonhomme ${ }^{2}$ and Sophie Arnaud-Haond ${ }^{2,4}$ \\ ${ }^{1}$ CCMar, Universidade do Algarve, Campus de Gambelas, 8005-139 FARO, Portugal \\ 2 Université Montpellier III; Laboratoire de Zoogéographie, Route de Mende, 34199 Montpellier Cedex 5, France \\ ${ }^{3}$ Laboratoire "Génome, Populations, Interactions", Station Méditerranéenne de l'Environnement Littoral, 34200 \\ Sète, France \\ ${ }^{4}$ Etude des Ecosystèmes Profonds (DEEP), Centre de Brest IFREMER, BP 70, 29280 Plouzané Cedex, France \\ *: Corresponding author : Regina L. Cunha, Phone : +351 289800900 ; Fax : +351 289800069 \\ email address : rcunha@ualg.pt
}

\begin{abstract}
:
Pearl oysters belonging to the genus Pinctada (Bivalvia: Pteriidae) are widely distributed between the Indo-Pacific and western Atlantic. The existence of both widely distributed and more restricted species makes this group a suitable model to study diversification patterns and prevailing modes of speciation. Phylogenies of eight out of the 11 currently recognised Pinctada species using mitochondrial (cox1) and nuclear (18S rRNA) data yielded two monophyletic groups that correspond to shell size and presence/absence of hinge teeth. Character trace of these morphological characters onto the molecular phylogeny revealed a strong correlation. Pinctada margaritifera appears polyphyletic with specimens from Mauritius grouping in a different clade from others of the French Polynesia and Japan. Hence, P. margaritifera might represent a species complex, and specimens from Mauritius could represent a different species. Regarding the putative species complex Pinctada fucata/Pinctada martensii/Pinctada radiata/Pinctada imbricata, our molecular analyses question the taxonomic validity of the morphological characters used to discriminate $P$. fucata and $P$. martensii that exhibited the lowest genetic divergence and are most likely conspecific as they clustered together. $P$. radiata and $P$. imbricata were recovered as monophyletic. The absence of overlapping distributions between sister lineages and the observed isolation by distance suggests that allopatry is the prevailing speciation mode in Pinctada. Bayesian dating analysis indicated a Miocene origin for the genus, which is consistent with the fossil record. The northward movement of the Australian plate throughout the Miocene played an important role in the diversification process within Pinctada.
\end{abstract}

Keywords : Pinctada - Evolutionary patterns - Species complex - Allopatry - Biogeography 


\section{Introduction}

The observed repeated instances of speciation in marine organisms with high dispersal abilities (Taylor and Hellberg, 2003, Williams and Reid, 2004, Paulay and Meyer, 2006) challenge the classical model for diversification in allopatry as a rare event in the sea. The analysis of present-day distribution patterns allows assessing the influence of past tectonic, climatic, and oceanographic changes (Frey and Vermeij, 2008) on species distribution. Biogeographic patterns may be shaped by vicariant events associated to isolation and largescale barriers (Lessios et al., 2001) or founder dispersal, both consistent with an allopatric mode of speciation (Paulay and Meyer, 2002, Williams and Reid, 2004). Any attempt at unravelling the origin of ancient speciation requires first the reconstruction of a robust phylogenetic framework and accurate dating of cladogenetic events (Arbogast and Slowinski, 1998, Rüber et al., 2003, McCafferty et al., 2002, Rutschmann et al., 2007). Pearl oysters belonging to the genus Pinctada (Bivalvia: Pteriidae) are widely distributed between the IndoPacific and western Atlantic (Fig. 1) tropical and subtropical shallow-water areas, most of them associated to reef environments (Strack, 2008). The extended larval duration of Pinctada species spanning from 16 to 30 days (Gervis and Sims, 1992) likely played a role in the broad distribution of the genus. The existence of both widely distributed (e.g., Pinctada margaritifera in the Indo-Pacific region) and more localised Pinctada species (e.g., Pinctada mazatlanica 
in the Gulf of California) makes this genus a suitable model group to study diversification patterns, and to assess the prevailing mode of speciation. The genus is included in the family Pteriidae, which origin based on the fossil record is placed in the Triassic, approximately 230 million years ago (Hertlein and Cox, 1969, Skelton and Benton, 1993). The fossil record of Pinctada is much more recent dating back to the Miocene of Western Europe and Caucasus (Hertlein and Cox, 1969, Caretto, 1975, Caretto et al., 1989).

The taxonomy of pearl oyster species is complex because shells are quite similar (Masaoka and Kobayashi, 2005) and there are not many morphological diagnosable characters available for species determination (Wada and Tëmkin, 2008). Classification is mainly based on soft tissues and shell characters (colour and shape) (Ranson, 1961). Yet, as for many bivalve species soft tissues exhibit few informative characters and shell morphology is difficult to distinguish in younger specimens (Wang et al., 2004). Moreover, high levels of phenotypic plasticity were detected in response to environmental heterogeneity (Hollander, 2008). The current classification of species may be erroneous because previous taxonomic work on pearl oysters was exclusively based on morphological characters and did not take into account intraspecific variation (Wada and Tëmkin, 2008). According to Ranson (1961), eleven species are recognised while other authors agreed on the existence of more than fourteen in the Indo-Pacific region (Hynd, 1955, Wada and Tëmkin, 2008). Due to extensive morphological variation among populations, the species Pinctada fucata, Pinctada martensii, Pinctada radiata and Pinctada imbricata, also called the Akoya pearl oysters, are presumed to belong to a species complex. P. radiata has a broad geographic distribution including the Mediterranean Sea, eastern Indian Ocean, and 
Red Sea/Persian Gulf regions, whereas $P$. imbricata is only found in the western Atlantic. P. fucata and P. martensii are found in the Indo-Pacific region (Wada and Tëmkin, 2008). Jameson (1901) indicated the existence of several subspecies within Pinctada margaritifera including e.g., P. m. cumingii (Central Pacific), P. m. zanzibarensis (Mauritius), and P. m. mazatlanica (Gulf of California). Furthermore, the genetic structure found between populations of $P$. margaritifera within the Central Pacific archipelagos using mtDNA and nuclear markers also suggested the existence of another species complex (Arnaud-Haond et al., 2003b, Arnaud-Haond et al., 2008).

Several phylogenetic hypotheses have been proposed for the genus. A morphology-based phylogeny analysing relationships within the superfamily Pterioidea yielded a topology in which $P$. fucata grouped with $P$. mazatlanica to the exclusion of $P$. imbricata (Tëmkin, 2006). Although not relying on a phylogenetic framework, Jameson (1901) proposed the existence of two major groups defined by morphological criteria: species with smaller shells and hinge teeth, which are structures that ensure a proper closure of shell valves ( $P$. radiata Leach, 1814, $P$. fucata Gould, 1850, P. imbricata Röding, 1798, and P. martensii Ranson, 1961), and species with larger shells without hinge teeth (Pinctada mazatlanica Hanley, 1855, $P$. maxima Jameson, 1901, and P. margaritifera Linnaeus, 1758). Most of the molecular studies performed thus far analysed genetic structure of a single species within the genus (e.g., P. margaritifera (Arnaud-Haond et al., 2004, Arnaud-Haond et al., 2008), or P. mazatlanica (Arnaud-Haond et al., 2000)). The most complete attempt to resolve phylogenetic relationships within the genus was based on nuclear internal transcribed spacer markers and found a close relationship between $P$. maxima and $P$. margaritifera (Yu and Chu, 2006, Yu et al., 2006). Nevertheless, these authors were 
unable to resolve phylogenetic relationships within the above referred species complex, and only used two species from the larger shelled group recognized by Jameson (1901).

In the present study, we examined phylogenetic relationships among eight species belonging to the genus Pinctada based on a fragment of the mitochondrial (mt) cytochrome oxidase subunit I ( $\operatorname{cox} l)$ and the complete nucleotide sequence of the nuclear $18 \mathrm{~S}$ ribosomal RNA genes. The reconstructed phylogenies were used to (1) analyse morphological patterns regarding shell size and presence/absence of hinge teeth testing for their correlation with molecular phylogenetic patterns; (2) infer the geographical patterns of speciation and date major cladogenetic events within the genus; (3) shed light on the prevailing mode of speciation, i.e. allopatry or sympatry.

\section{METHODS}

\section{DNA extraction, amplification and sequencing}

To assess phylogenetic relationships of the pearl oysters, we used 43 specimens (38 from this study) belonging to the genus Pinctada representing eight out of the 11 currently recognized species within the genus (see Table 1 for sample locations). Three other Pteriidae, Pteria sterna, Pteria hirundo, and Pteria loveni, are the closest sister genus to Pinctada and were chosen as the outgroup (Tëmkin, 2006). Tissue samples were preserved in 70-100\% ethanol, and total genomic DNA was isolated using SDS/proteinase K digestion, and Phenol-Chloroform extraction method (Sambrook et al., 1989). The specific primers LCX 5'-TCG TAT AGA GCT CCG TCG ACC TG-3' and HCY 5'-TGG AAC AAA ACT GGA TCG CC -3' designed in a previous study (Arnaud-Haond et al., 2000, Arnaud-Haond et al., 2003a) were used 
to amplify a fragment of about 600 base pairs of the mitochondrial cytochrome oxidase subunit I ( $\operatorname{cox} 1)$ gene. PCR amplifications were carried out in 25 or $50 \mu 1$ reactions using the following final concentrations: 10x PCR polymerase buffer (Promega), $2.5 \mathrm{mM}$ of $\mathrm{MgCl}_{2}, 2 \mathrm{mM}$ of each dNTP, $0.6 \mu \mathrm{M}$ of each primer, and 0.8 to 2 units of Taq polymerase. The following profile was used: an initial denaturing step at $94{ }^{\circ} \mathrm{C}$ for $3 \mathrm{~min} ; 30$ cycles of denaturing at $94^{\circ} \mathrm{C}$ for $1 \mathrm{~min}$, annealing at $45^{\circ} \mathrm{C}$ for 1 min, and extending at $72^{\circ} \mathrm{C}$ for $1 \mathrm{~min}$; and a final extending step at $72^{\circ} \mathrm{C}$ for $5 \mathrm{~min}$. PCR amplicons were purified either by using the two enzymes Presequencing Kit (Eurogentec), or the Gene Clean Kit (Pharmacia Biotech.) and directly sequenced with the corresponding PCR primers. Sequencing was performed in an automated sequencer (ABI PRISM 3700) using the BigDye® Terminator v3.1 Cycle Sequencing Kit (Applied Biosystems), and following manufacturer's instructions.

\section{Phylogenetic reconstruction}

Alignments of nucleotide sequences were constructed with CLUSTAL X version 1.83 using default parameters (Thompson et al., 1997), and verified by eye in order to maximise positional homology. Two different data sets were analysed: (1) partial nucleotide sequences of the cox $1 \mathrm{mt}$ gene of 43 specimens representing eight species of Pinctada and the three outgroup (Pteria sterna, Pteria hirundo, Pteria loveni) produced an alignment of 506 base pairs (bp). Of these, 209 were constant and 248 were parsimony informative, and (2) partial nucleotide sequences of the mt coxl (506 bp) of seven specimens representing each one a species of Pinctada (this study), and the complete nuclear 18S ribosomal RNA genes from seven Pinctada species retrieved from GenBank were combined into a single data set that produced an 
alignment of 2,333 bp. Of these, 2,107 were constant and 167 were parsimony informative. Pteria hirundo was used as outgroup.

The Akaike Information Criterion (AIC) (Akaike, 1973) implemented in Modeltest v.3.7 (Posada and Crandall, 1998) was used to determine the evolutionary model that best fits the data sets.

Bayesian analysis - Bayesian inferences (BI) were conducted with MRBAYEs v3.1.2 (Huelsenbeck and Ronquist, 2001). Four Metropolis-coupled Markov chain Monte Carlo (MCMC) analyses were run for one million generations, and sampled every 100 generations. Two independent runs were performed for each data set. The mtDNA data set was analysed under the GTR $+\Gamma$, and the burn-in was 80,000 generations. The best-fit model for the nuclear data set was HKY+I, and the burn-in was 100,000 generations. The $\mathrm{mt}$ and nuclear partitions of the combined data set were analysed under the GTR $+\Gamma$, and HKY + I models, respectively. Model parameters were estimated independently for the two data partitions using the "unlink" command in MrBAYEs. The burn-in in the combined analysis was set to 60,000 generations. Robustness of the inferred trees was evaluated using Bayesian posterior probabilities (BPPs). BI analyses were carried out using the resources of the Computational Biology Service Unit from Cornell University (http://cbsuapps.tc.cornell.edu/).

Maximum likelihood (ML) analyses - PHYML v2.4.4 (Guindon and Gascuel, 2003) was used to estimate the ML tree, and to test by nonparametric bootstrap proportions (BPs) the robustness of the inferred trees using 1000 pseudoreplicates. The GTR $+\Gamma$ model was selected for the mt coxl data set, whereas HKY+I was the best evolutionary model for the nuclear data set. The selected model for the combined 
data set used in $\mathrm{ML}$ analysis was the $\operatorname{TrN}+\mathrm{I}+\Gamma$. Because $\operatorname{TrN}+\mathrm{I}+\Gamma$ model is not available in PHYML, the GTR $+\mathrm{I}+\Gamma$ (the second best-fit model, according to Modeltest) was used in the ML analysis of the combined data set. All ML analyses were carried out on the freely available Bioportal (http://www.bioportal.uio.no).

\section{Divergence time estimation}

Divergence times of the main cladogenetic events in the Pinctada phylogeny were estimated using a relaxed molecular clock Bayesian approach as implemented in BEAST version 1.4.8 (Drummond and Rambaut, 2007) using the mitochondrial data set because it maximises the number of analysed taxa. This methodology uses probabilistic calibration priors instead of point calibrations, allowing the incorporation of fossil uncertainties (Drummond et al., 2006). Two calibration points were provided by placing a Lognormal prior distribution on the age of the stem lineages of the genus Pinctada, and of the species $P$. mazatlanica. The first calibration point was based on the approximate age of first occurrence of Pinctada in the fossil record during the Miocene between 23 and 5.3 million years ago (MYA) (Hertlein and Cox, 1969). The second calibration point was based on the existence of a fossil of $P$. mazatlanica reported from the Pliocene of Baja California between 1.8 and 5.33 MYA (Moore, 1983). We choose the Yule speciation model that assumes a constant rate of speciation, following a pure birth-dead process (Yule, 1924) as suggested in (Drummond et al., 2006). This estimate assumes a constant rate of speciation but uses the phylogenetic information in the tree to estimate number of the lineages at the end and beginning of the time. The analysis was performed under the GTR (General Time Reversible) substitution model, rate variation among sites was 
modelled using a discrete gamma distribution with four categories, and in addition, the proportion of invariant sites was estimated. MCMC were performed in BEAST with $20,000,000$ steps, following a discarded burn-in of 2,000,000 steps. The convergence of the chains to the stationary distribution was confirmed by inspection of the MCMC samples using the program TRACER v1.4 (Rambaut and Drummond, 2007) that provides a measure of whether the chain has run for an adequate length.

\section{Correlation between presence/absence of hinged teeth, and shell size with molecular phylogeny of Pinctada}

In order to evaluate whether there is a significant clustering of Pinctada species and presence/absence of hinged teeth we used MacClade v. 4.03 (Maddison and Maddison, 2001). Two character states ("hinge teeth present" and "hinge teeth absent") were mapped onto the mitochondrial tree (because it maximises the number of analysed taxa) using information from the literature (Tëmkin, 2006, Wada and Tëmkin, 2008). The same procedure was applied to the character shell size, with two character states ("small" and "large") to analyse if there is correlation between shell size and the phylogenetic patterns based on the tree. See table 2 for further information on character mapping.

\section{RESULTS}

\section{Mitochondrial data set}

The BI analysis based on a fragment of the mt $\operatorname{cox} 1$ gene yielded the tree $(-\ln L=$ 3934.17) shown in Figure 2. Two main clades that included smaller pearl oyster 
species with hinge teeth (hereafter "smaller-toothed" clade) and larger species without hinge teeth (hereafter "larger-toothless" clade) were evidenced, but only the later displayed a significant BPP value (99\%).

The "small-toothed" clade included species belonging to the putative complex Pinctada fucata/P. martensii/P. imbricata/P. radiata, and $P$. maculata. This later species, from the central part of Ryūkyū archipelago (Okinawa Island) in SE Japan, was found in a basal position with respect to the rest of specimens belonging to the "smaller toothed" clade. P. radiata and $P$. imbricata were both monophyletic, whereas $P$. martensii and $P$. fucata clustered together in the same clade (Fig. 2). $P$. imbricata is the sister lineage of the clade (P. fucata $+P$. martensii) to the exclusion of $P$. radiata.

The "larger toothless" clade included Pinctada mazatlanica, P. margaritifera and $P$. maxima. In this clade, only P. mazatlanica from the Gulf of California was monophyletic grouping with specimens of $P$. margaritifera from French Polynesia, and with a specimen from Okinawa Island. The two specimens of $P$. margaritifera from Mauritius (southwest Indian Ocean) clustered together in a basal position with respect to the remaining $P$. margaritifera specimens. $P$. maxima from Japan clustered with the Japanese specimen of $P$. margaritifera, suggesting a possible misidentification of this particular sample, as the remaining specimens of $P$. maxima from Australia clustered together in a rather divergent clade. The ML analysis showed the same topology $(-\ln L=3881.78)$ as the BI analysis.

\section{Combined data set}


$\mathrm{BI}$ analysis of the combined data set of partial mt coxl and complete nuclear $18 \mathrm{~S}$ rRNA genes yielded the topology $(-\ln L=5366.98)$ depicted in the inset from figure

2. The two main clades ("smaller toothed" and "larger-toothless") were also recovered with BPP values of 87 and100, respectively. This topology only differs from the mt-based topology in the relative phylogenetic position of $P$. imbricata that groups with $P$. radiata instead of being part of the polytomy with $P$. fucata $+P$. martensii and P. radiata (see Fig.2). The reconstructed topology from the ML analysis (- $\ln L=5749.24)$ was identical to the BI tree (not shown).

\section{Pearl oysters divergence time estimation}

The divergence time obtained with BEAST between both main clades that included species with hinge teeth ("smaller toothed" clade) and without ("larger-toothless" clade) was estimated at $13.68[7.33,20.09]$ MYA (Fig. 3). The estimated time of the most recent common ancestor (TMRCA) of "larger-toothless" clade was 8 MYA, comparable to the TMRCA of the "smaller toothed" clade origin estimated at 8.5 MYA. Within the "larger-toothless" clade, the divergence between P. margaritifera from Mauritius (Indian Ocean) and the clade that grouped P. margaritifera from French Polynesia with P. mazatlanica was estimated at 6.9 MYA. Within the "smaller toothed" clade, the estimated TMRCAs of $P$. radiata and $P$. imbricata were 1.3 and 0.35 MYA, respectively (Fig. 3). P. martensii and $P$. fucata grouped in the same clade which TMRCA was estimated at 0.85 MYA.

Correlation between presence/absence of hinge teeth and shell size with Pinctada phylogeny 
The projection of the two-states character "hinge teeth present" and "hinge teeth absent" into the Pinctada mitochondrial BI tree (Fig. 4 -A) resulted in a 1-step tree, which was not in the $95 \%$ confidence interval of the null distribution. We also traced shell size with two character states "large" and "small" (Fig. 4 -B) into the BI tree, and the resultant 1-step tree was not included in the $95 \%$ confidence interval of the null distribution. These results indicate that the presence/absence of hinged teeth is significantly correlated with the molecular phylogeny as well as shell size.

\section{DisCUSSION}

\section{Phylogenetic patterns of Pinctada and systematic implications}

The taxonomy of pearl oysters has been traditionally based on shell features (shape and colour) (Hertlein and Cox, 1969, Oliver, 1992), which are recognisably plastic characters largely influenced by environmental factors and heterogeneity among habitats (Hollander, 2008). Species identification is particularly difficult in juveniles because of shell similarity (Wada and Tëmkin, 2008) and the use of molecular data has shown to be quite useful to infer phylogenetic relationships in groups having insufficient, or uninformative morphological diagnosable characters (Wahlberg et al., 2005). Disagreement between morphological and molecular data was also reported for some bivalve genera (Wang et al., 2004).

In this study, phylogenetic analyses based on a fragment of the mt cox 1 gene revealed two distinct monophyletic groups according to shell size, and presence/absence of hinge teeth: the "smaller-toothed" and the "larger-toothless" clades. The existence of these two main clades and the strong correlation found 
between morphological characters and the phylogeny (Fig. 4) might result either from random drift, or from an early character divergence induced by natural selection. Two evolutionary processes induced by natural selection i.e., character displacement and/or size assortment (Radtkey et al., 1997) might also play a role in the divergence observed here. However, with the available data it is not possible to distinguish between these hypotheses.

Some of the currently recognised Pinctada species used in this study were not monophyletic according to the mitochondrial-based analyses. Only P. mazatlanica, $P$. radiata, and $P$. imbricata were reciprocally monophyletic, and thus concordant with the taxonomy of the genus. Regarding $P$. maxima, the specimen that grouped with $P$. margaritifera was most likely misidentified because of the reduced genetic distance found between the two species (both sequences belong to Japanese specimens, retrieved from the GenBank). The species P. margaritifera is polyphyletic clustering specimens from Mauritius (southwest Indian Ocean) in a different clade from other P. margaritifera from the French Polynesia and Japan. Additionally, specimens from French Polynesia are closer to P. mazatlanica rather than to $P$. margaritifera from Mauritius. P. margaritifera might therefore represent a species complex in which the taxon from Mauritius would represent a different species. The polyphyletic nature of $P$. margaritifera supported by the molecular analyses performed in this study was already intuitively speculated based on its wide distribution and intraspecific morphological variation (Allan, 1959). Jameson (1901) also recognised the existence of six subspecies within $P$. margaritifera including $P$. margaritifera mazatlanica in the American Pacific coast that was later acknowledged as a distinct species (Ranson, 1961). 
No inferences can be made about $P$. maculata on the basis of a single specimen, but it seems to be quite divergent from the remaining "smaller toothed" species. Regarding the putative species complex Pinctada fucatal P. martensiil P. radiatal $P$. imbricata, our molecular analyses question the taxonomic validity of the morphological characters used to discriminate $P$. fucata and $P$. martensii, as they clustered together (see Fig. 2), but support the taxonomic status of the species $P$. radiata and $P$. imbricata. These analyses are partially in agreement with a previous molecular study of eight species of pearl oysters based on ITS nuclear markers (Yu and Chu, 2006). Yet, some results presented here clearly contradict this previous molecular analysis. For instance, our mitochondrial-based topology showed a polytomy with three well-suported clades including (1) P. imbricata, (2) P. radiata, and (3) P. fucata/P. martensii (Fig. 2) whereas in the above-mentioned ITS study, all three species were included within the same clade. Many studies report incongruence between mitochondrial and nuclear-based phylogenies because, for instance, of stochastic sorting of ancestral polymorphisms, introgressive hybridisation, or different modes of inheritance (Moore, 1995, Sota and Vogler, 2001). To overcome these effects it is recommended to use independent markers. Accordingly, we also included a combined data set of $\mathrm{mt}$ (cox1, $506 \mathrm{bp}$ ) and nuclear (complete 18S rRNA, 2,333 bp) genes that lead to identical results as the mt-based phylogeny. The two main clades based on shell size and presence/absence of hinge teeth were also recovered in the combined analyses (see the inset from Fig. 2) as well as the doubtful taxonomic status of the species $P$. fucata and $P$. martensii that exhibited the lowest genetic divergence, and are most likely conspecific. 


\section{Phylogenetic patterns and allopatry as the dominant speciation mode in Pinctada}

\section{pearl oysters}

Marine species with long-lived pelagic larvae usually exhibit wide geographical ranges. Populations are expected to be large due to high gene flow and thus, speciation through allopatry would be a rare event in the sea (Palumbi, 1994). If sympatry is the dominant process of speciation, it is expected that sister-species exhibit overlapping distributions, whereas complete disjunction would be expected in case of allopatry (Meyer, 2003). Although this general pattern might be obscured when species range shifts subsequently to lineage sorting, the analysis at genus level may still reflect the prevailing mode of speciation.

Despite Pinctada species exhibit a long larval phase between 16 and 30 days (Gervis and Sims, 1992), phylogeographic patterns reported here are consistent with an allopatric mode of speciation. The absence of overlapping distributions is noticeable in most of the species within the genus Pinctada. Only P. fucata and P. martensii sister lineages show overlapping distributions as they co-exist in sympatry. Yet, our analyses suggest that these taxa might be conspecific and their taxonomic status should be revisited. If allopatry was achieved by increasing geographical distance it is expected that specimens separated by vast stretches of open sea would group in different clades, as is the case for P. margaritifera specimens from Mauritius (Indian Ocean) that group in a different clade of specimens from the French Polynesia (South Pacific), or from Japan (see Fig. 2). If the prevailing speciation mode in Pinctada is sympatry, we would expect $P$. maculata (from Japan) to be the sister species of the clade P. fucata+P. martensii (also from Japan) but instead occupies a basal position with respect to the entire "smaller-toothed" clade. 
Recent evidence suggests that allopatric speciation in marine planktonic species maybe more common than previously expected (McCartney et al., 2000, Lessios et al., 2001, McCafferty et al., 2002, Williams and Reid, 2004). Maximum limits for dispersal are not established but most of the Pinctada species present a wide distribution throughout the Indo-Pacific region, presumably due to a long larval development between 16 and 30 days (Gervis and Sims, 1992). In marine species with a sedentary life-style as adults, the duration of pelagic larval stage is a proxy for dispersal potential and often determines geographic range size variation (Lester and Ruttenberg, 2005). It is indeed the case for oysters from the genus Crassostrea (Lapègue et al., 2002) exhibiting larval duration and geographical ranges similar to Pinctada. Despite Pinctada extensive geographical distribution, the existence of genetic structure within the Central Pacific archipelagos was already reported in $P$. margaritifera using mtDNA and nuclear markers (Arnaud-Haond et al., 2003a), or between Australian and Indonesian populations of $P$. maxima, using microsatellites (Benzie and Smith-Keune, 2006). Those results suggest that differentiation can occur at the scale of several hundreds kilometres regardless the extensive larval dispersal potential further supporting the hypothesis that allopatric speciation may be the prevailing speciation mode within this genus.

Allopatry can result from vicariant events, founder dispersal or most frequently a combination of both mechanisms (Paulay and Meyer, 2002). Vicariance is a possible explanation when clades show sets of species belonging to each region and species divergence is in agreement with the estimated timing of biogeographical events. Investigating present-day distribution patterns requires the understanding of how the marine realm was affected by tectonic events, oceanographic and climatic 
changes over evolutionary timescales (Vermeij, 1987). The northward movement of the Australian plate throughout the Miocene [20.03 - 5.3 MYA] and following uplift of the Indian archipelago caused deep changes in the Indo-Pacific region, decreasing significantly the contact between the Pacific and Indian basins (Hodell and Vayavananda, 1993). The "smaller-toothed" clade is arranged into three monophyletic groups that embrace a broad geographic distribution. This phylogenetic pattern allows hypothesizing about the geographic range occupied by the ancestral lineage that gave rise to this clade. According to our age estimates, the "smallertoothed" clade originated in the Miocene. The northward movement of the Australian plate throughout the Miocene might have isolated $P$. radiata of the Persian Gulf from species of the western Pacific (P. fucata and P. martensii) yielding the observed modern biogeographical pattern. Within the "larger toothless" clade, $P$. margaritifera shows a polyphyletic pattern in which species from Mauritius do not group in the same cluster of specimens of the French Polynesia. This divergent phylogenetic pattern might also result from the northward movement of the Australian plate during the Miocene considering that the divergence of these two $P$. margaritifera lineages occurred during the same period.

Founder speciation occurs whenever colonists successfully establish in a region where gene flow is sufficiently limited with the initial source population (s) to allow differentiation (Paulay and Meyer, 2002). Endemic species on islands are classical examples of this type of allopatric speciation. The apparent lack of endemic species restricted to isolated oceanic archipelagos, despite restriction to gene flow at the within species level, suggests that founder events might occur but gene flow would be sufficient to prevent speciation at limited spatial scale in some widespread 
Pinctada species, most likely due to their long pelagic larval duration. Yet, it has been suggested that a species from the Hawaii Islands currently considered as a subspecies of $P$. margaritifera ( $P$. margaritifera galtsoffi) might represent a true species (Wada and Tëmkin, 2008) and thus, the vast stretch of open water that surrounds this oceanic islands would be an effective barrier to gene flow. As we could not access to samples from these areas, further analyses including specimens from Hawaii are needed to confirm the taxonomic status of $P$. margaritifera in those islands and test the hypothesis of founder speciation.

In conclusion, the presented data has shed light on some relevant aspects of the evolution of the genus Pinctada, i.e., (1) the existence of two main groups according to shell size and presence/absence of hinge teeth correlated with the reconstructed molecular phylogeny; (2) the close relationship concerning the estimated time of divergence between $P$. radiata and $P$. fucata/P. martensii, or between specimens of $P$. margaritifera from the Pacific and Indian oceans, and the northward movement of the Australian plate during the Miocene, supports the role played by vicariance in the speciation process of Pinctada; (3) according to the obtained phylogeographic clades allopatry emerges as the prevailing speciation mode in Pinctada. 


\section{ACKNOWLEDGEMENTS}

We thank Rita Castilho for helpful discussions and for drawing figures 1, 3, and 4 .

We are very grateful to Annie Orth for maintaining collections in liquid nitrogen for ages, and to Christelle Campanini for sequencing $P$. fucata (GenBank accession number GQ355871). 


\section{References}

AKAIKE, H. (1973) Information theory as an extension of the maximum likelihood principle. IN CSAKSI, B. N. P. A. F. (Ed.) 2nd International Symposium on Information Theory. Budapest, Hungary, Akademiai Kiado.

ALLAN, J. (1959) Australian shells with related animals living in the sea, in freshwater and on the land, Boston, MA, Charles T. Brandford Company.

ARBOGAST, B. S. \& SLOWINSKI, J. B. (1998) Pleistocene Speciation and the Mitochondrial DNA Clock. Science, 282, 1955.

ARNAUD-HAOND, S., BONHOMME, F. \& BLANC, F. (2003a) Large discrepancies in differentiation of allozymes, nuclear and mitochondrial DNA loci in recently founded Pacific populations of the pearl oyster Pinctada margaritifera. Journal of Evolutionary Biology, 16, 388-398.

ARNAUD-HAOND, S., MONTEFORTE, M., BLANC, F. \& BONHOMME, F. (2003b) Evidence for male-biased effective sex ratio and recent step-by-step colonization in the bivalve Pinctada mazatlanica. Journal of Evolutionary Biology, 16, 790-796.

ARNAUD-HAOND, S., MONTEFORTE, M., BONHOMME, F. \& BLANC, F. (2000) Population structure and genetic variability of pearl oyster Pinctada mazatlanica along Pacific coasts from Mexico to Panama. Conservation Genetics, 299-307.

ARNAUD-HAOND, S., VONAU, V., BOUDRY, P., BLANC, F., PROU, J., SEAMAN, T. \& GOYARD, E. (2004) Spatio-temporal variation in the genetic composition of wild populations of pearl oyster (Pinctada margaritifera cumingii) in French Polynesia following 10 years of juvenile translocation. Molecular Ecology, 13, 2001-2007.

ARNAUD-HAOND, S., VONAU, V., ROUXEL, C., BONHOMME, F., PROU, J., GOYARD, E. \& BOUDRY, P. (2008) Genetic structure at different spatial scales in the pearl oyster (Pinctada margaritifera cumingii) in French Polynesian lagoons: beware of sampling strategy and genetic patchiness. Marine Biology, 155, 147-157.

BENZIE, J. A. \& SMITH-KEUNE, C. (2006) Microsatellite variation in Australian and Indonesian pearl oyster Pinctada maxima populations. Marine Ecology Progress Series, 314, 197-211.

CARETTO, P. G. (1975) Un raro lamellibranco perlifero nel Pliocene Piemontese. Atti della Società Italiana di Scienze Naturali e del Museo Civico di Storia Naturale di Milano, 116, 33-64.

CARETTO, P. G., DURAND, P. \& BLANC, F. (1989) Apport de l'analyse biométrique à l'étude des relations phylogénétiques de la nacre fossile Pteria margaritifera studeri (Mayer) (Mollusque, bivalve, Pteriidae). Atti della Società Italiana di Scienze Naturali e del Museo Civico di Storia Naturale di Milano, 130, 205-216.

DRUMMOND, A. J., HO, S. Y. W., PHILIPS, M. J. \& RAMBAUT, A. (2006) Relaxed Phylogenetics and Dating with Confidence. PLoS Biology, 4, e88.

DRUMMOND, A. J. \& RAMBAUT, A. (2007) BEAST: Bayesian evolutionary analysis by sampling trees. BMC Evolutionary Biology, 7, 214. 
FREY, M. A. \& VERMEIJ, G. J. (2008) Molecular phylogenies and historical biogeography of a circumtropical group of gastropods (Genus: Nerita): Implications for regional diversity patterns in the marine tropics Molecular Phylogenetics and Evolution, 48, 1067-1086.

GERVIS, M. H. \& SIMS, N. A. (1992) The biology and culture of pearl oysters (Bivalvia: Pteriidae), London, England, The WorldFish Center.

GUINDON, S. \& GASCUEL, O. (2003) A simple, fast and accurate algorithm to estimate large phylogenies by maximum likelihood. Systematic Biology, 52, 696-704.

HERTLEIN, L. G. \& COX, L. R. (1969) Family Pteriidae Gray, 1847 (1820). IN COX, L. R., NEWELL, N. D., BOYD, D. W., BRANSON, C. C., CASEY, R., CHAVAN, R., COOGAN, A. H., DECHASEAUX, A. H., FLEMING, C., HAAS, C. A., HERTLEIN, F., KAUFFMAN, L. G., KEEN, E. G., LAROCQUE, A. M., MCALESTER, A. L., MOORE, A. L., NUTTAL, R. C., PERKINS, B. F., PURI, H. S., SMITH, L. A., SOOT-RYEN, T., STENZEL, H. B., TRUEMAN, E. R., TURNER, R. D. \& WEIR, J. (Eds.) Treatise on invertebrate paleontology. Part N. Mollusca 6: Bivalvia. Vol. 1. Lawrence, Kansas, Geological Society of America and University of Kansas.

HODELL, D. A. \& VAYAVANANDA, A. (1993) Middle Miocene paleooceanography of the western equatorial Pacific (DSDP site 289) and the evolution of Globorotalia (Fohsella). Marine Micropaleontology, 22, 279310.

HOLLANDER, J. (2008) Testing the grain-size model for the evolution of phenotypic plasticity Evolution, 62, 1381-1389.

HUELSENBECK, J. P. \& RONQUIST, F. R. (2001) MrBayes: Bayesian inference of phylogeny. Bioinformatics, 17, 754-755.

HYND, J. S. (1955) A Revision of the Australian pearl-shells, genus Pinctada (Lamellibranchia). Australian Journal of Marine Freshwater Research, 6, 98137.

JAMESON, H. L. (1901) On the identity and distribution of the mother-of-pearl oysters; with a revision of the sub-genus Margaritifera. Proceedings of the general meetings for scientific business of the Zoological Society of London 1, 372-394.

LAPÈGUE, S., BOUTET, I., LEITÃO, A., HEURTEBISE, S., GARCIA, P., THIRIOT-QUIÉVREUX, C. \& BOUDRY, P. (2002) Trans-Atlantic distribution of a mangrove oyster species revealed by $16 \mathrm{~S}$ mtDNA and karyological analyses. Biological Bulletin, 202, 232-242.

LESSIOS, H. A., KESSING, B. D. \& PEARSE, J. S. (2001) Population structure and speciation in tropical seas: global phylogeography of the sea urchin Diadema. Evolution, 55, 955-975.

LESTER, S. A. \& RUTTENBERG, B. (2005) The relationship between pelagic larval duration and range size in tropical reef fishes: a synthetic analysis.

Proceedings of the Royal Society of London Series B-Biological Sciences, 272, 585-591.

MADDISON, W. P. \& MADDISON, D. R. (2001) MacClade 4 version 4.03PPC. IN ASSOCIATES, S. (Ed.) Sunderland, Massachussets. 
MASAOKA, T. \& KOBAYASHI, T. (2005) Natural hybridization between Pinctada fucata and Pinctada maculata inferred from internal transcribed spacer regions of nuclear ribosomal RNA genes. Fisheries Science, 71, 829-836.

MCCAFFERTY, S., BERMINGHAM, E., QUENOUILLE, B., PLANES, S., HOELZER, G. \& ASOH, K. (2002) Historical biogeography and molecular systematics of the Indo-Pacific genus Dascyllus (Teleostei: Pomacentridae). Molecular Ecology, 11, 1377-1392.

MCCARTNEY, M. A., KELLER, G. \& LESSIOS, H. A. (2000) Dispersal barriers in tropical oceans and speciation in Atlantic and eastern Pacific sea urchins of the genus Echinometra. Molecular Ecology, 9, 1391-1400.

MEYER, C. P. (2003) Molecular systematics of cowries (Gastropoda: Cypraeidae) and diversification patterns in the tropics. Biological Journal of the Linnean Society, 79, 401-459.

MOORE, E. J. (1983) Tertiary marine pelecypods of California and Baja California: Nuculidae through Malleidae. Geological Survey Professional Paper, 1228-A, A1-A108.

MOORE, W. S. (1995) Inferring phylogenies from mtDNA variation: mitochondrialgene trees versus nuclear-gene trees. Evolution, 49, 718-726.

OLIVER, P. G. (1992) Bivalved seashells of the Red Sea, Wiesbaden and Cardiff, Hemmen and National Museum of Wales.

PALUMBI, S. R. (1994) Genetic divergence, reproductive isolation, and marine speciation. Annual Review of Ecology \& Systematics, 25, 547-572.

PAULAY, G. \& MEYER, C. (2002) Diversification in the Tropical Pacific: Comparisons Between Marine and Terrestrial Systems and the Importance of Founder Speciation. Integr. Comp. Biol., 42, 922-934.

PAULAY, G. \& MEYER, C. (2006) Dispersal and divergence across the greatest ocean region: do larvae matter? Integrative and Comparative Biology, 46, 269-281.

POSADA, D. \& CRANDALL, E. D. (1998) Modeltest: testing the model of DNA substitution. Bioinformatics, 14, 817-818.

RADTKEY, R. R., FALLON, S. M. \& CASE, T. J. (1997) Character displacement in some Cnemidophorus lizards revisited: A phylogenetic analysis. PNAS, 94, 9740-9745.

RAMBAUT, A. \& DRUMMOND, A. J. (2007) Tracer version 1.4. IN HTTP://BEAST.BIO.ED.AC.UK/TRACER (Ed.).

RANSON, G. (1961) Les especes d'huitres perliéres du genre Pinctada (biologie de quelques-unes d'entre elles). IN BELGIQUE, I. R. D. S. N. D. (Ed.) Mémoires, deuxieme serie, fasc. 67.

RÜBER, L., VAN TASSELL, J. L. \& ZARDOYA, R. (2003) Rapid Speciation and Ecological Divergence in the American Seven-Spined Gobies (Gobiidae, Gobiosomatini) Inferred from a Molecular Phylogeny. Evolution, 57, 15841598.

RUTSCHMANN, F., ERKISSON, T., ASALIM, K. A. \& CONTI, E. (2007) Assessing Calibration Uncertainty in Molecular Dating: The Assignment of Fossils to Alternative Calibration Points. Systematic Biology, 56, 591-608.

SAMBROOK, J., FRITSCH, E. F. \& MANIATIS, T. (1989) Molecular cloning, N.Y., Cold Spring Harbor laboratory. 
SKELTON, P. W. \& BENTON, M. J. (1993) Mollusca:Rostroconchia, Scaphopoda and Bivalvia. IN BENTON, M. J. (Ed.) The fossil record2. London, Chapman $\&$ Hall.

SOTA, T. \& VOGLER, A. P. (2001) Incongruence of mitochondrial and nuclear gene trees in the Carabid beetles Ohomopterus. Systematic Biology, 50, 39-59.

STRACK, E. (2008) Introduction. IN SOUTHGATE, P. C. \& LUCAS, J. S. (Eds.) The Pearl Oyster. Amsterdam, The Netherlands, Elsevier.

TAYLOR, M. S. \& HELLBERG, M. E. (2003) Genetic evidence for local retention of pelagic larvae in a Caribbean reef fish. Science, 299, 107-109.

TËMKIN, I. (2006) Morphological perspective on the classification and evolution of recent Pterioidea (Mollusca: Bivalvia). Zoological Journal of the Linnean Society, 148, 253-312.

THOMPSON, J. D., GIBSON, T. J., PLEWNIAK, F., JEANMOUGIN, J. \& HIGGINS, D. G. (1997) The Clustal X windows interface: Flexible strategies for multiple sequence alignment aided by quality analysis tools. Nucleic Acids Research, 25, 4876-4882.

VERMEIJ, G. J. (1987) The dispersal barrier in the tropical Pacific: implications for molluscan speciation and extinction. Evolution, 41, 1046-1058.

WADA, K. T. \& TËMKIN, I. (2008) Taxonomy and Phylogeny. IN SOUTHGATE, P. C. \& LUCAS, J. S. (Eds.) The Pearl Oyster. Amsterdam, The Netherlands, Elsevier.

WAHLBERG, N., BRABY, M. F., BROWER, A. V. Z., JONG, R., LEE, M., NYLIN, S., PIERCE, N. E., SPERLING, F. A. H., VILA, R., WARREN, A. D. \& EVGUENI (2005) Synergistic effects of combining morphological and molecular data in resolving the phylogeny of butterflies and skippers.

Proceedings of the Royal Society of London Series B-Biological Sciences, 272, 1577-1586.

WANG, H., GUO, X., ZHANG, G. \& ZHANGA, F. (2004) Classification of jinjiang oysters Crassostrea rivularis (Gould, 1861) from China, based on morphology and phylogenetic analysis Aquaculture, 242, 137-155.

WILLIAMS, S. T. \& REID, D. G. (2004) Speciation and diversity on tropical rocky shores: a global phylogeny of snails of the genus Echinolittorina. Evolution, $58,2227-2251$.

YU, D. H. \& CHU, K. H. (2006) Species identity and phylogenetic relationship of the pearl oysters in Pinctada Röding, 1798 based on ITS sequence analysis. Biochemical Systematics and Ecology, 34, 240-250.

YU, D. H., JIA, X. \& CHU, K. H. (2006) Common pearl oysters in China, Japan, and Australia are conspecific: evidence from ITS sequences and AFLP. Fisheries Science, 72, 1183-1190.

YULE, G. U. (1924) A mathematical theory of evolution, based on the conclusions of Dr. J. C. Willis. Philosophical Transactions of the Royal Society. London. Series B 213, 21-87. 


\section{Figure legends}

Figure 1. Approximate distribution of the species of Pinctada pearl oysters used in this study.

Figure 2. Phylogenetic relationships of the genus Pinctada based on a Bayesian inference (BI) analysis of a partial sequence data of the mitochondrial coxl gene using the GTR $+\Gamma$ evolutionary model. Species in bold were retrieved from GenBank. The inset shows a BI topology based on the combined data set (cox $1+18 \mathrm{~S}$ rRNA). Numbers in the nodes in both figures correspond to BI posterior probabilities (above branches) and maximum likelihood bootstrap proportions (below branches). Only values above $70 \%$ are represented.

Figure 3. Maximum clade credibility chronogram obtained with BEAST showing divergence dates of main cladogenetic events within the genus Pinctada. Divergence dates were estimated from the mitochondrial data set. Age estimates (above branches; in million years) and corresponding 95\% highest posterior density intervals (bars and values in square brackets, below branches) are depicted.

Figure 4. Tracing evolutionary changes of the characters shell size and presence/absence of hinge teeth on the BI mitochondrial-based phylogeny. A - shell size; $\mathbf{B}$ - presence/absence of hinge teeth. 



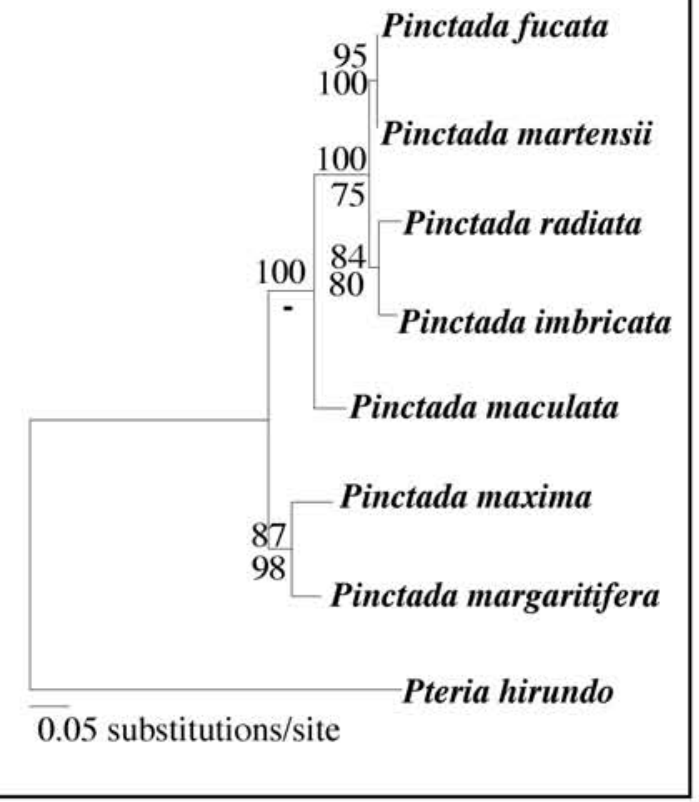

[P. mazatlanica 101

P. mazatlanica 105

99-P. mazatlanica 106

- P. mazatlanica 107

P. mazatlanica 110

P. mazatlanica 113

P. mazatlanica 102

100 P. mazatlanica 103

99

P. mazatlanica 104

P. mazatlanica 111

P. mazatlanica 112

P. mazatlanica 108

P. mazatlanica 109

100 P. margaritifera

100 P. maxima

P. margaritifera 101

97 - P. margaritifera 106

P. margaritifera 107 93/ -

P. margaritifera 111

P. margaritifera 109

87 - $P$. margaritifera 102

99

- - . margaritifera 103

P. margaritifera 104

-P. margaritifera 108

P. margaritifera 110

P. margaritifera 105

100 P. margaritifera zanzib1 Mauritius, western 100 . margaritifera zanzib4 Indian Ocean
French Polynesia

South Pacific

\begin{tabular}{c|c} 
Okinawa & wapan
\end{tabular}

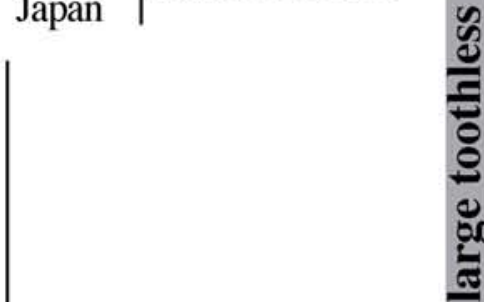

Gulf of California

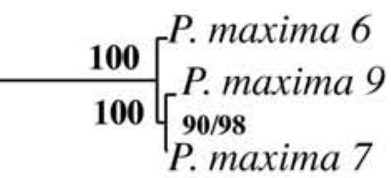

Australia, South Pacific

P. fucata

100

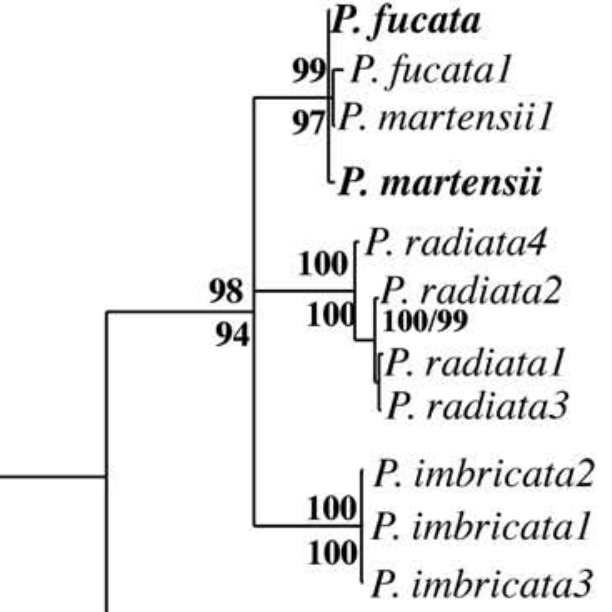

P. maculata

Japan, western Pacific

United Arab Emirates

Persian Gulf

Guadeloupe Island

western Atlantic

Okinawa, Japan, western Pacific

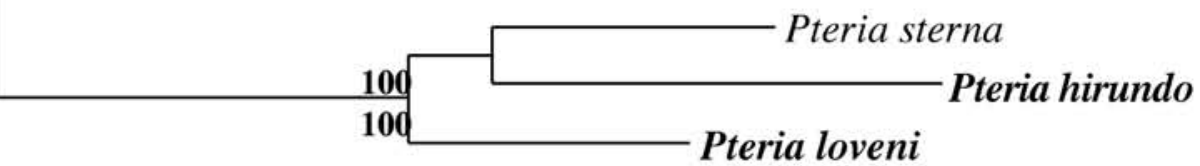




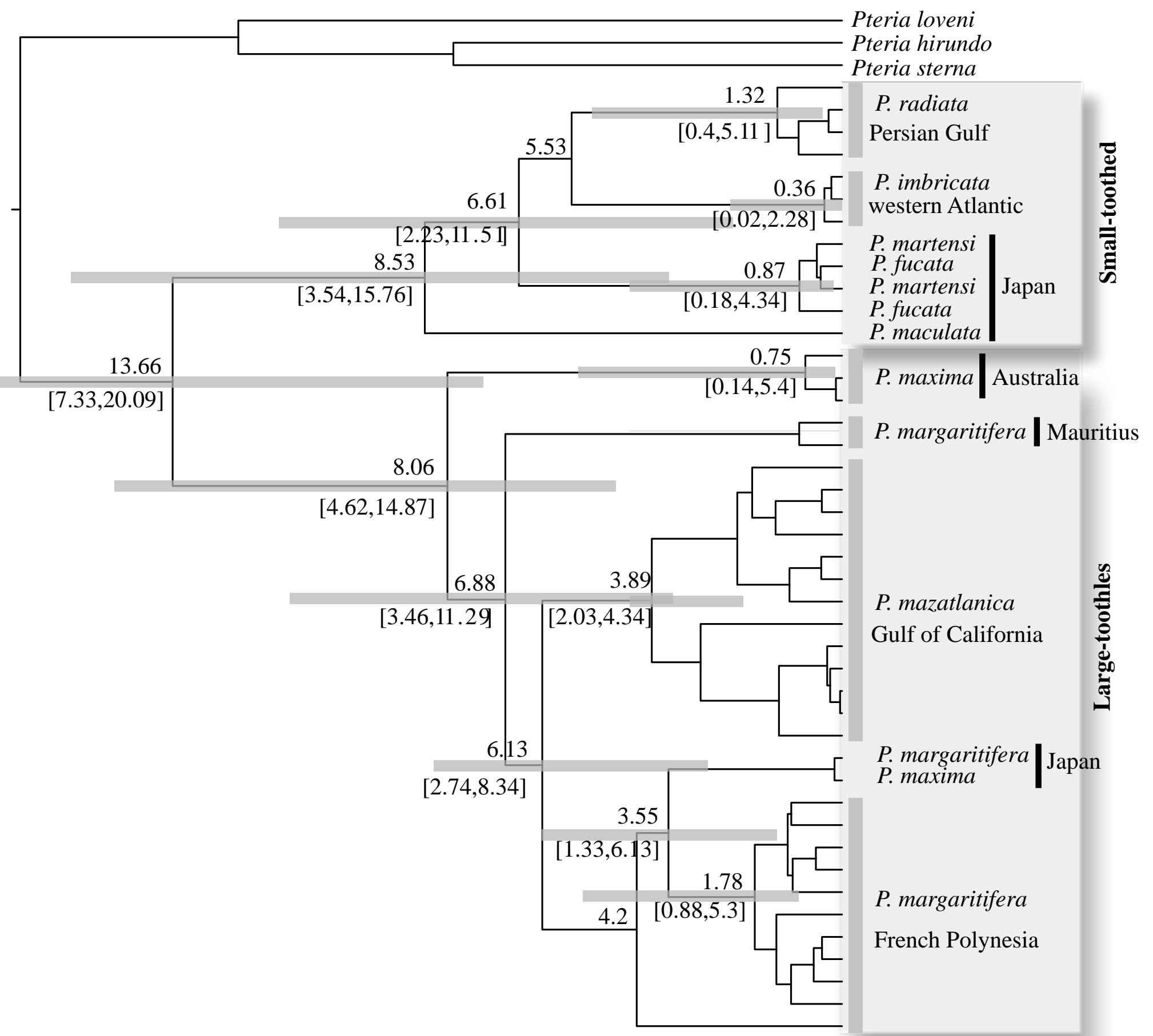


A

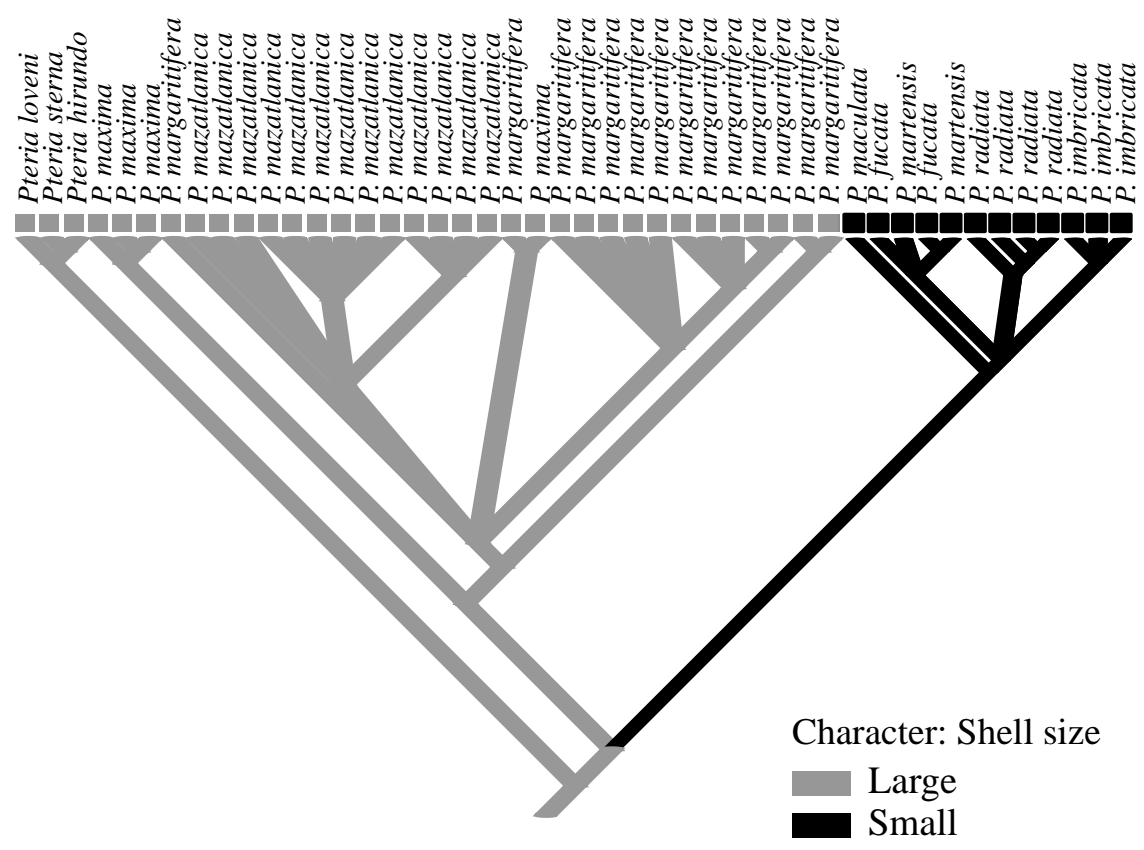

B

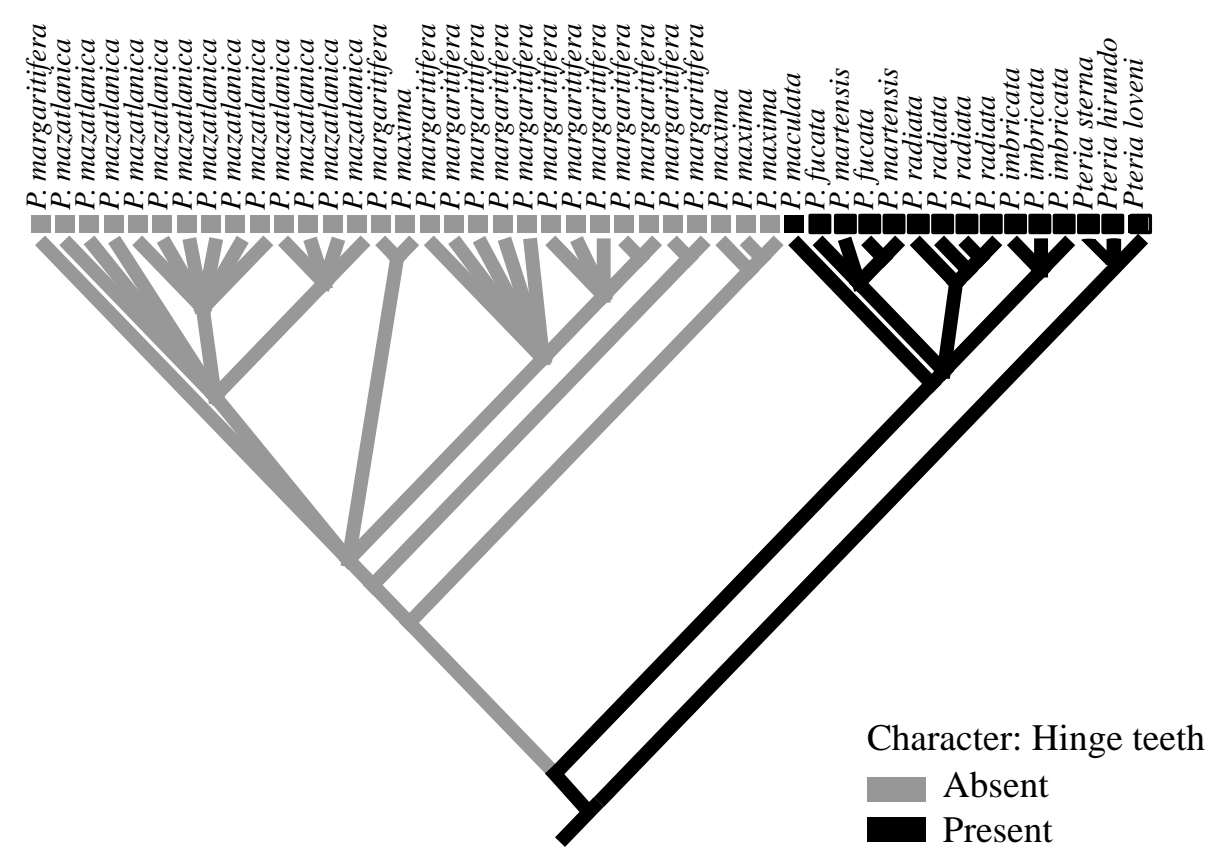

